\title{
The Moral Foundations of Criminal Liability
}

\section{Mouaid Al Qudah*}

Associate Professor in Criminal Law, School of Law, Sharjah University, UAE

*Corresponding author: Mouaid Al Qudah, Associate Professor in Criminal Law, School of Law, Sharjah University, UAE, Tel: 0509669317; E-mail: malqudah@sharjah.ac.ae

Rec date: Mar 4, 2014, Acc date: Apr 24, 2014, Pub date: May 4, 2014

Copyright: () 2014 Qudah MA. This is an open-access article distributed under the terms of the Creative Commons Attribution License, which permits unrestricted use, distribution, and reproduction in any medium, provided the original author and source are credited.

\begin{abstract}
This paper seeks to provide a theoretical account of the moral foundations of criminal liability. It does not seek to provide a general theory of criminalization. Rather, it aims to identify some moral principles and concepts which serve as a foundation and justification for criminalization and the imposition of criminal liability. Central to these moral foundations are the principles of 'individual autonomy', 'individual rights', 'the principle of welfare' and the 'harm principle'. This chapter undertakes to explore this issue through addressing the general question of 'what is a crime?' This question involves examining why a particular type of behaviour is considered to be criminal by the law, or what considerations need to be taken into account in order to render a particular type of behaviour criminal, and to consequently justify the imposition of criminal liability.
\end{abstract}

Keywords: Criminal liability; Crime; Individual autonomy; Individual rights

\section{Introduction}

It is possible to approach the answer to the question 'what is a crime?'1, from a variety of theoretical perspectives. Broadly speaking, differing theoretical perspectives can be divided into two categories: positivist theory and non-positivist theory. Positivist theory merely provides a descriptive answer to the question of 'what is a crime', without seeking to provide moral justifications for criminalization and the imposition of criminal liability. In contrast, non-positivist theory seeks to provide moral justifications and explanations by considering ethical principles including individual autonomy, individual rights, and the principle of welfare and the causing of harm.

\section{The Question 'What is a Crime?'}

\section{Positivist theory}

Positivist theory is mainly concerned with 'what is the law' and not with 'what the law ought to be'. Davies (2002:90-92) points out that positivism pays a great deal of attention to pure legal doctrine and not the social, political and moral/ethical context of law. Positivism as a legal philosophical theory conceives law as rules created by human beings and imposed on other people. From a positivist point of view, legal philosophy should not be concerned with speculation about the morality of law, but needs to be concerned with arriving at an understanding of the nature of law as it exists. For positivism, there is no necessary connection between law and morality, even if law may sometimes accord with a moral standard. Law is pure rules formulated and applied by human beings, and these rules remain law even if they do not accord with moral principles or standards [1]. One of the earliest exponents of the positivist view was John Austin who, in The Province of Jurisprudence Determined [2] describes what the law is, and not what the law ought to be [3]. Austin distinguishes between positive law and morality, natural law and norms associated with social behaviours. For Austin, the difference between law and the other norms or rules lies in the type of sanction or punishment applied. Austin argues that the infringement of a social rule would result in no more than social disapproval, whereas the infringement of a legal rule would result in a legal consequence such as punishment, fine or damage award. These legal consequences are determined and applied by courts and other legal institutions. Austin perceives law as orders or commands given to human beings by a superior sovereign. Such commands are generally obeyed by subjects, with punishment and sanctions attached for the breaching of them.

The modern exposition of positivism comes with the work of Professor H L A Hart, The Concept of Law ${ }^{2}$. Hart criticises the notion of sovereignty in itself as a necessary feature of the legal system, and postulates that the foundations of a legal system rest on a combination of rules which can be recognized, applied and understood by reference to other rules. Hart divides the law into two groups of rules: the primary rules which relate to the substantive law such as the road rules or the law of negligence, and the secondary rules which are procedural in nature and relate to the way in which the substantive rules can be ascertained, introduced, changed or eliminated. Hart asserts that the

1 For further discussion of this question see for example Brett P, An Inquiry into Criminal Guilt, The Law Book Co, Australia, 1963 at 6-36; Lacey N \& Wells C \& Meure D, Reconstructing Criminal Law: Critical Perspective on Crime and the Criminal Process, Weidenfeld and Nicolson, London, 1990 at 12-17; Smith J, Criminal Law, 9th ed, Butterworths, London, 1999 at 15-18; Waller L \& Williams C R, Criminal Law: Text and Cases, 6th ed, Butterworths, Sydney, 1989 at 3-4; Elliott D W \& Well C, Casebook on Criminal Law, 4th ed, Sweet \&Maxwell, London, 1982 at 1-12.

2 For a summary on how Kelsen explains the validity of law see Paulson B L \& Paulson S L (trans); Introduction to the Problems of Legal Theory by Hans Kelsen, Oxford University Press, United States, 1992 at chapter 5; Davies M, 2002 supra at 96-102; Freeman M D A, 2001 supra at 256-263; Morrison W, 1997 supra at 323-350; Harris J W, 1980 supra at 59-73. 
Page 2 of 10

combination of these rules alone is not sufficient to label a certain system of rules as a legal system. He indicates that for these to be regarded as legal rules there should be a 'rule of recognition' which would give the primary and secondary rules their legal characterization. For Hart, the rule of recognition represents the attitudes of officials of the legal system [4].

Another philosopher who has attempted to define law is Hans Kelsen [5]. Kelsen explains the validity of law by reference to what he calls the 'basic norm'. He argues that laws in a legal system are bound together in a hierarchical order, related to each other as parts of the system. For Kelsen, the validity of a norm/law rests upon and can only be explained by reference to another higher norm/law. This hierarchical structure continues until the 'basic norm' (Grundnorm) is reached, which is the common bond of all norms in a legal system. Kelsen considers that sanctions or penalties are necessary for a norm to be regarded as a legal norm. He treats the breaching of a legal norm as a crime 'delict'. This means, according to Kelsen, that when a certain norm is breached a type of sanction would be applied by officials against those who breached it. Namely, sanction and coercion in the form of applying sanctions by officials in the legal systems are necessary features of the criminal law ${ }^{3}[6,7]$.

Positivists define crime by the institutional and procedural responses to a particular behaviour. These responses include the prohibition of certain behaviour by criminal law in the first place, prosecution of that behaviour through certain criminal legal processes carried out by criminal legal agencies, and consequently the application of punishment by courts ${ }^{4}$, (I shall refer to this as the 'procedural consequences criterion'). The definition of crime under this criterion was well-illustrated by the statement made by Lord Atkin in Proprietary Articles Trade Association v Attorney-General [1931] AC 310 at p324: 'the criminal quality of an act cannot be discerned by intuition; nor can it be discovered by reference to any standard but one: is the act prohibited with penal consequences?' Defining crime by reference to such a procedural criterion is a dominant feature of the work of many legal commentators in common law jurisdiction. For example, Kenny (1936) defines crime by reference to the criminal process, stating that: 'crime is a wrong whose sanction is punitive, and which is in no way remissible by any private person, but is remissible by the crown alone, if remissible at all' (p16). In a similar vein, Glanville Williams (1983) defines crime as: 'a legal wrong that can be followed by criminal proceedings which may result in punishment' (p27) [8]. Similarly, in Jordan (a civil law jurisdiction), writings on the criminal law in general, and on the definition of crime in particular, focus on the description of the criminal law in a positivist fashion. For example, a crime is defined as an offence which consists of two components, the actus reus and the mens rea, and deserves punishment as indicated by the Code [9].

Under the 'procedural consequences criterion' crime has been defined by reference to two indicators. First, conduct is considered a crime because it is defined as a crime by criminal law. It is the lawmakers, whether legislators or judges, who determine what types of acts should be classified as crimes. Accordingly, it can be argued that crimes are those behaviours considered criminal by criminal law, and all that is required to identify crimes is to examine the criminal law in a given legal system to discover what behaviours are defined as crimes. For example, the JPC provides examples of the types of acts treated as crimes under Jordanian law. The JPC broadly classifies crimes into different categories. Examples of these include: crimes against the security of state such as treason; crimes against public safety such as possession of weapons and ammunition; crimes against the administration of justice such as concealing of felonies and misdemeanours; crimes against religion and family such as publicly breaking the fast in the month of Ramadan and adultery; crimes against public morality such as rape, sexual assault, soliciting of a woman for prostitution; crimes against the person such as murder; and crimes against property such as theft and fraud. Similarly, the Crimes Act 1900 (NSW) includes different categories of acts treated as crimes. These include for instance, crimes against the person such as homicide; crimes against public order such as riot; and crimes against property such as larceny. Obviously, it is easy to say that a crime is an act (or omission) that breaches the criminal law (Marsh, 1986:2). However, the question remains: does this definition provide any clue as to why criminal law has selected these behaviours and classified them as crimes? It seems the answer to this question is no.

The second indicator of crime under the 'procedural consequences criterion' is the criminal-civil wrongs and procedures distinction, and the role the state plays in criminal proceedings. The following specific issues illustrate this distinction. First, the state plays a greater role in criminal proceedings than in civil proceedings. Generally, a criminal trial is seen to be a battle between the state and the citizen, whereas a civil trial is a battle between private citizens (Rush, 1997:6). Kenny (1936:14-17) states that the difference between criminal and civil processes might be discovered if the control exercised by the state over them were perceived. For Kenny, the ultimate distinction between the two kinds of processes lies in the fact that the punishment of criminal procedures is remissible by the Crown and no private person can grant a valid remission for any criminal sanction, whereas he or she can exercise the power, if any, of remitting a sanction of a civil procedure. In other words, as Rush (1997:7) points out, according to Kenny this means that the state has the authority to pardon criminal sanctions.

Second, another difference between the two types of procedures depends on the place in which they are employed. The machinery by which criminal law is applied refers to agencies of the criminal justice system such as the police, prosecutors and courts. The perception that crimes are prosecutable indicates that they are inseparable from the criminal proceedings, and the test of whether conduct is criminal is the nature of proceedings which are set to follow an allegation that this conduct has been committed (Gillies, 1993:5-6). Kenny (1936:11) argues that although criminal procedures take place in criminal courts

3 For a similar definition see Marsh I, Crime, Longman Group Limited, Unit Stated of America, 1986 at 2; Pike L O, History of crime in England, William S.Hein \& Company, Buffalo, 1983 at 489-490; Cole G F \& Smith C E, Criminal justice in America, Wadsworth Publishing Company, New York, 1996 at 5; Napley D, Crime and Criminal Procedure, Oyez Publications, London, 1963 at 5; Fleming M, Of Crimes and Rights: The Penal Code Viewed as a Bill of Rights, W.W Norton \& Company Inc, New York, 1978 at 31.

4 See for example Alseid K, Explanation of the General Principles in The Penal Code of Jordan: Comparative Study: Crime, Criminal Participation, Criminal Liability and punishment, The Arabic Centre for Students Services, Jordan, 1998 at 32-33; Najem M S, Explanation of the Jordanian Penal Code: The General Part, Dar Althakafah Press, Jordan, 1991 at 9; Alhalabi M A, Explanation of the Penal Code: The General Part, Dar Althkafah Press, Jordan, 1997 at 93- 95; Garar K, Explanation of the Jordanian Penal Code: The General Part, Jordan, 1978 at 37. 
whereas civil procedures take place in civil courts, this is not necessarily a crucial feature in defining crime, since both types of procedures may at times take place in the same court. Furthermore, it can be argued that conduct is criminal not because it is triable in a criminal court but only when the court has determined that it is. Therefore, this distinction between an act triable in a criminal court and another in a civil court fails to differentiate criminal wrong and civil wrong.

Third, punishment is the aim of criminal procedure whereas compensation is the object of civil procedure (Kenny, 1936:11-12; Rush, 1997:6; Dine, 1995:11). That is to say, if punishment was the outcome of a certain case, then this is an indicator that the behaviourwhich was the subject of that case- is criminal behaviour. In contrast, if the outcome of the case was compensation or any other civil remedy, then this is an indication that the behaviour- subject to that case- was not criminal. Punishment has certain features which would make it possible to distinguish it from other unpleasant consequences. These features include pain, retribution, rehabilitation and deterrence. However, as Kenny (1936:12-13) observes, defining crime by reference to a criminal-civil procedures distinction is inconclusive. This means that some civil processes could be brought with punitive aims, such as exemplary damages where the court might wish not only to compensate the victim of a tort, but to punish the defendant by taking into account the degree of violence or malice or oppressiveness in his or her act. Furthermore, it might be argued that the labelling of certain behaviour as criminal is not dependent on the type of procedures applicable, rather the definition of criminal proceedings is dependent on the fact that they apply following the commission of a crime.

In sum, although many commentators have defined crime by reference to 'the procedural consequences criterion' it is generally accepted that this definition is dogged by the problem of circularity. Williams (1983:28) defends his definition and argues that it is not circular, while others (Rush, 1997: 8-9; Murugason and McNamara, 1997:1; Gillies, 1993:5) rebut this. They argue that the definition is circular, since on the one hand crime is defined by reference to criminal law, and as being subject to be followed by criminal procedures resulting in unpleasant outcomes. On the other hand, criminal law is that which defines crime, and criminal procedures and unpleasant outcomes are those which follow the commission of a crime. The 'procedural consequences criterion' does not reflect the moral foundations for criminalisation and the imposition of criminal liability. It provides a descriptive, rather than explanatory, definition of crime. Obviously, defining crime by reference to the 'procedural consequences criterion does not provide any clue as to why a particular act is treated as a crime in the first place. Therefore, the answer to the question 'what is a crime?' should be sought elsewhere by exploring natural, social and ethical ways of defining crime. As Roberts (2001-2002) points out in order to determine whether a particular form of conduct should be criminalized it is always necessary to pose [the question]: is there a good (moral) reason to justify extending the criminal law to this particular conduct?' (p217). To this issue the following discussion now turns.

\section{The natural, social and ethical way: 'non-positivism'}

As stated earlier, this way of defining crime is mainly concerned with providing moral justifications for criminalization and the imposition of criminal liability. These involve reference to basic moral concepts and principles, including the principles of individual autonomy, individual rights, the principle of welfare and harm. As Lacey (1988) points out, 'the criminal law can be conceived as a set of norms...the function of which is to protect the autonomy and welfare of individuals and groups in society with respect to a set of basic goods, both individual and collective' (pp104-105). Along the same lines, Ashworth (1999:26-58) considers the principle of individual autonomy and the principle of welfare and the prevention of harm to either or both of them as the principles which ought to have a bearing in relation to criminalization and the imposition of criminal liability. The following discussion addresses these moral foundations.

\section{The principle of individual autonomy [10]}

One of the fundamental concepts involved in the justification of criminalization is the principle of individual autonomy, and as far as criminalization is concerned, a key concept here is that of individual rights. Before addressing this, it is useful to briefly explore the elements of the principle of individual autonomy.

Ashworth (1999:27) points out that the principle of individual autonomy has two elements: factual and normative. The factual element of the autonomy principle perceives individuals as having the capacity and sufficient free will to make meaningful choices. An autonomous person is one who has the ability to choose, formulate and carry out his or her plans along with his or her ability to govern personal conduct by rules and values (Downie \& Calman, 1994:52). In principle, commentators recognise that criminal law perceives individuals as having freedom to make choices (Hodgson, 2000:655) although this might be displaced in certain circumstances by factors such as duress or necessity ${ }^{5}$. In other words, with the acknowledgment of the role of influences and circumstances, criminal law regards individuals as autonomous and rational agents who have conceptions of what they are doing, generally considered as not compelled in their decisions and actions (Jacobs, 2001:10-11; Coles \& Jang, 1996:64). In this regard Barbara Hudson et al. [11] states that:

The notion of free will that is assumed in ideas of culpability... is a much stronger notion than that usually experienced by the poor and powerless. That individuals have choices is a basic legal assumption: that circumstances constrain choices is not (p302).

The second element of the principle of individual autonomy is the normative one. That is, individuals should be respected and treated as agents capable of choosing their actions; without allowing such independence of actions it would hardly be possible to regard individuals as moral persons [12]. The respect of an individual as an autonomous being involves taking into account that he or she is selfdetermining and self-governing along with his or her capability to act autonomously (Downie \& Calman, 1994:54). Ashworth (1999:29) points out that in liberal theory, the principle of autonomy goes much further than this. It postulates that individuals should be left to decide for themselves in every aspect of their lives. This is well demonstrated in the statement of the liberal theorist Joel Feinberg (1986) [13]:

The most basic autonomy-right is the right to decide how one is to live one's life, in particular how to make the critical life-decision -what course of study to take, what skills and virtues to cultivate, what career to enter, whom or whether to marry, which church if any to join, whether to have children, and so on.

5 This will be further discussed in chapter 3: Individual Autonomy as a Ground of criminal culpability. 
Returning to the issue of criminalisation, a key concept noted above is that of individual rights. Such rights are connected to autonomy and free action insofar as they are thought of as entitlements to avail oneself of particular resources in light of free individual decisions and choices ${ }^{6}$. These rights include, among others, the right to liberty, the right of personal safety, property protection and so on. It is also worth noting that responsibility is the flip side of autonomy. That is, if a person autonomously infringes upon the rights of others, then they should bear responsibility for the infringement ${ }^{7}$. Liberal theorists such as Hobbes and Locke place great emphasis on the respect of the liberty of individuals, postulating that they should be left free to choose actions or omissions without any intervention by criminal law unless necessary to prevent the causing of harm to others [14]. From the perspective of the principle of autonomy, criminalisation is justified to prevent and punish infringements of the rights of others, including the right to life, personal safety, property and so forth.

This relationship between autonomy and rights entails providing a description of what is a right or when a person is said to have a legal right. As Freeman (2001:355-354) points out, Hohfeld's account of rights (1913-1914; 1916-1917) [15] is the most rigorous and remains the source to which most return. Therefore, it is important to consider Hohfeld's analysis of 'rights' to provide insight into what a right is. Hohfeld (1913-1914: 28-59) distinguishes four senses in which a person may have a legal right.

First are rights which correlate with duties. For Hohfeld, to say that the correlative of a right is a duty is to say that a right entails a duty: if $\mathrm{X}$ has a right against $\mathrm{Y}$ that $\mathrm{Y}$ shall stay off $\mathrm{X}$ 's land, the correlative and equivalent is that $\mathrm{Y}$ is under a duty toward $\mathrm{X}$ to stay off the land. However, Edmundson (2004:99) questions whether the entailment goes both ways between the correlatives or one way only: do duties entail rights? Freeman (2001:357) and Edmundson (2004:99) point out that whilst Hohfeld is correct to state that every right 'stricto sensu' implies the existence of a correlative duty, non-correlative duties do not seem to have a place in Hohfeld's scheme. In this regard, it can be argued that a deontological and rights-based theory is helpful in providing insight into duties and their correlative rights. Ridley (1998:11, 34-38) comments that from a deontological perspective, individual acts are ethically acceptable whenever they accord with their duties and obligations, and that when a deontological theory lays down duties and obligations of certain kinds it inevitably lays down rights corresponding to these.

Broadly speaking, individuals are supposed to have some basic rights. These rights, among others, include the right to life, the right to freedom, the right to personal safety, the right to property protection and so on. Ridley (1998:43) argues that to assume that someone has a certain right is to say that he or she is owed an obligation of some kind by other persons. To that effect, Benn (1988:236) maintains that to say someone has a right to $\mathrm{X}$ is to say that by virtue of a set of normative relations that hold between that person and another person, there are certain demands such that his or her making them would be a reason for the other person's acceding to them, and would put the latter in the wrong if, without some overriding reason, he or she did not accede to them. Duties and rights are like the opposite side of a coin, that is, an individual's duty is another individual's right and vice versa.
The second sense in which Hohfeld defines rights is those which amount to privileges or liberties and negate duties. For example, where A has a right against B that B shall stay off A's land, A himself or herself has the privilege of entering the land or does not have a duty to stay off that land, and correlatively no one has the right to demand that A stay off the land. The third sense in which a person may have a legal right according to Hohfeld is when that right amounts to power. The power is the legal ability to bring about a change in the legal relations between the person who holds the power and another. For example, if A has the power to dissolve his or her legal interests in his or her property through abandonment, then correlative to this power is the liability of others to have their legal relations changed through its exercise. Finally, Hohfeld identifies rights which give immunity. Immunity is the negation of liability: it consists of the freedom from legal power or control of another regarding certain legal relations. The immunity of certain charitable institutions from taxation is an example.

A meaningful possession of a right entails the protection of that right in circumstances in which it is violated or appears likely to be violated [16]. As Mill (1861) says, 'to have a right, then, is, I conceive, to have something which society ought to defend me in the possession of (p66) [17]. One way of achieving the protection of rights is through the intervention of criminal law to prevent the violation of rights and hold responsible transgressors. For example, X's right to life imposes a duty on $\mathrm{Y}$ not to kill $\mathrm{X}$, and if $\mathrm{Y}$ does not uphold his or her duty and kills X, Y should be liable for that actions. To assume that someone has a right entails the protection of the possession of that right. Arguably, the protection of an individual's rights renders their possession by that individual meaningful, and contributes to the furtherance of 'general utility' (Wolff, 1996:130). Utilitarianism advocates the maximisation of general happiness and the minimisation of total pain. As such, the argument could be that a place where individuals are given a sphere of protected rights would be happier than one without such protection. Thus, the intervention of criminal law to protect an individual's rights can be justified on utilitarian grounds. In order to achieve its purpose, this intervention should be subject to some limitations. On the one hand, it should be subject to the requirement of 'rule utilitarianism': providing a set of rules which if followed would maximise the total happiness of all (Ridley, 1998: 28-34). On the other hand, it should be a minimal intervention which is necessary to safeguard and protect the interest of individuals. Bentham (1948:171) asserts that if punishing particular conduct would result in more harmful consequences than those which it prevented, that conduct should be left unpunished.

Basically, the principle of individual autonomy assigns great importance to the freedom and liberty of individuals while preventing harm being caused by others. That is, individuals should be protected from the interference of criminal law through criminalisation and the imposition of criminal liability unless they can be shown to have chosen the actions for which they might be held criminally liable, and that these affect others ${ }^{8}$. The principle of individual autonomy advocates that there should be no interference with the liberty of individuals if their autonomy is to be respected, and it stands for significant protection of individual rights and interests. This emphasis on the respect of individual rights militates also against the criminalisation of behaviours on the basis of 'paternalism'. In other

\footnotetext{
$6 \quad$ The relation between rights and autonomy will be further developed when the notion of harm is dealt with below.

The way in which the autonomy of individuals operates to form a ground for criminal liability will be discussed in the following chapter.

8 This will be developed in more detail when J S Mill's 'harm principle' is discussed later in this chapter.
} 
words, criminal law should not interfere with the liberty of individuals for their own good by criminalising behaviours which are harmless to themselves ${ }^{9}$, such as homosexual behaviours.

Three main features characterize the Wolff (1996:144) points out that communitarians maintain that liberalism conceives of individuals as isolated people having no essential attachment to the society in which they live, and thus having the right to pursue their own good however they wish. However, the question arises as to how sustainable such a claim is: that individuals are free to pursue their own good however they wish. Ashworth (1999:29) points out that the notion of liberal individualism to be free to do as one wish is quite unsustainable without a range of qualifications. Modern liberal theorists enhance these qualifications through the development of autonomy-based theories which place emphasis on collective goals as a necessary condition for maximum autonomy. This is well illustrated in Joseph Raz's argument (1986) [18]:

Autonomy-based doctrine of freedom. First, its primary concern is the promotion and protection of positive freedom which is understood as the capacity for autonomy, consisting of the availability of an adequate range of options, and of the mental abilities necessary for an autonomous life. Second, the state has the duty not merely to prevent the denial of freedom, but also to promote it by creating the conditions of autonomy. Third, one may not pursue any goal by means which infringe people's autonomy unless action is justified by the need to protect or promote the autonomy of those people or of others (p425).

Clearly, the principle of individual autonomy assumes that one is free to make choices on how to live, and that individuals are entitled to pursue their private interests however they wish. In the same vein, the autonomy principle allows individuals to be held responsible if their actions are harmful to others. Moreover, as Raz remarks, the intervention with an individual's liberty can be justified on the basis of promoting collective goals which considered as necessary conditions to the enhancement of maximum autonomy. This point is discussed below, as I consider the principle of welfare.

\section{The principle of welfare}

The welfare principle advocates preserving the collective good of the community, such as environmental, health and security protection and public safety. From the perspective of the welfare principle, the protection of collective or aggregate interests is necessary to enhance the general well-being of the community, and criminal law is one way of denouncing and punishing any behaviour which might threaten these interests, even if it results in the liberty of individuals being sacrificed.

The starting point for the welfare principle is the social nature of individuals. As a social being, an individual's identity and selfunderstanding are bound up with the society in which he or she lives. An individual is born into a family which is itself part of a tribe or clan and a larger community. As Feinberg (1988) argues it is absurd...to think of an individual as formed prior to and independently of his socialization in a particular social group, capable of living in isolation from any community' (p84). Wolff (1996:144) states that from a communitarian perspective, if individuals did not find themselves in a particular social setting, they would be quite different. This view was first acknowledged by Mill et al. (1962), where he states:
The social state is at once so natural, so necessary, and so habitual to man, that, except in some unusual circumstances or by an effort of voluntary abstraction, he never conceives himself otherwise than as a member of a body; and this association is riveted more and more, as mankind is further removed from the state of savage independence. Any condition, therefore, which is essential to a state of society, becomes more and more an inseparable part of every person's conception of the state of things which he is born into, and which is the destiny of a human being (pp284-5) [19].

The central point for communitarian theorists, unlike liberal theorists, is their focus on the social nature of human beings, arguing that denial of the importance of the community we live in would lead to individual alienation and ultimately the dislocation of society. Ashworth (1999:30) and Findlay et al (1999:4) point out that the principle of welfare places an emphasis on the centrality of the collective goals of existing society. Nicola Lacey (1988) describes the principle of welfare as including the 'fulfillment of certain basic interests such as maintaining one's personal safety, health and capacity to pursue one's chosen life plan' (p104) [20]. This view is similar to that which Rousseau's social philosophy [21] postulates. For Rousseau, human beings have the right to a life of equality and liberty in a simple community. He maintains that in a free society people would gain freedom which could only be limited by what he termed the 'general will'. In Rousseau's view, the 'general will' is considered the will of the community as a unified whole, expressing its general interest since the individual's will is contained in the general will, it cannot be limited by it (one's own will cannot limit one's freedom).

The communitarian principle of welfare then, views individuals as social beings, and entitled to liberty as described by Rousseau and communitarians ${ }^{10}$ : an individual could not be made free in isolation, requiring that they be brought to a position where correct choices concerning how to live can be made. This process would teach individuals about their interests and those of their society, facilitating the realisation that it would be in no one's interest to act so as to undermine their society and consequently their identities. Noticeably, much of the argument about the principle of welfare depends on definitions of 'community' [22], 'collective goals' or 'general interests' or 'the common good'.

However, the aim here is not to engage in a detailed discussion of how the notion of society has developed, or to try to attempt a conclusive definition of what would constitute the common good. Rather, the aim here is to emphasise the idea that, on the one hand individuals are social beings having the tendency to live together, with each having his or her own interests in personal safety, property protection and so on. Actions which might threaten these interests would seem to affect a nameable person in advance, and consequently criminalisation could be justified on the grounds of protecting such interests. On the other hand, however, one can conceive some common interests which are perceived as a collection of certain interests possessed by a large number of individuals, belonging to everyone in the community. These include environmental protection, public safety, food safety and so on. The assumption is that although an act which threatens them would threaten no specific person nameable in advance, it may affect anyone who happened to be in a position to be affected.

\footnotetext{
9 This point will be discussed further below.

10 See Wolff J, 1996 supra at 145.
} 
As such, it is in the interest of every individual to have these interests protected in order to enhance the well-being of the community. One can conceive that injury to the good of the community is ultimately harmed to the interests of its individual members (Feinberg, 1988:89). Bearing this in mind, it is possible to imagine that some people would insist on exceeding the limits, attempting to infringe on both individual and collective interests. Therefore, a need for some kind of safeguard to ensure the protection of these collective interests is necessary. The impetus for the need to protect collective interests was recognized by social philosophers ${ }^{11}$ writing about the state of nature such as Aquinas and Rousseau. Moreover, liberal theorists such as Hobbes and Locke also acknowledged this need. For example, Hobbes considers it necessary to escape from the state of nature where people are entitled to do whatever is necessary to secure their survival without regard as to whether or not this would harm others. A solution perceived by Hobbes, Locke, Rousseau, Kant and Hume was to enter into a contract and to transfer the right of punishing the transgressor to a sovereign. This sovereign would possess all the legislative, judicial and executive powers necessary to safeguard the interests of the people who had authorized this.

In sum, one can conceive of a type of symbiotic relationship between protecting the collective and individual interests in a given society from harmful actions. Arguably, the protection of the collective good is ultimately a protection of the interests of the individuals who live in that society. By the same token, the protection of the interests of individuals would ultimately promote the common good of that society. This issue is further elaborated in the next section.

\section{The harmfulness of behaviors}

The harmfulness of behaviours as a moral foundation for criminalization and the imposition of criminal liability can be considered from two perspectives. First, harm can be considered in a 'physical' sense, which I refer to as the 'harm principle'. According to this principle, the type of harm which might invoke criminalization is defined by reference to the principles of autonomy and welfare, as discussed below. Secondly, there is an extended notion of harm as advocated by Lord Devlin, which seeks to support the criminalization of behaviours considered by some to potentially affect the moral cohesion of society. According to this notion, the harm involved is perceived in a 'non-physical' sense, which I shall refer to as the 'moral notion of harm'.

\section{Harm principle}

Harmfulness as an intrinsic feature of conduct is one of the starting points when discussing issues of criminalization and the imposition of criminal liability. A number of questions will be addressed while exploring 'the harm principle'. These include the question of when the harmfulness of certain behaviour justifies the imposition of criminal liability. What kinds of harm should the criminal law be concerned with to criminalize? When does the 'harm principle' fail to justify criminalization? Is harm a justifiable criterion for criminalization, and why?

While considering the harm principle, it is appropriate to introduce it with the statement made by its foremost historical champion, John Stuart Mill [23].
The only purpose for which power can be rightfully exercised over any member of a civilized community, against his will, is to prevent harm to others. His own good, either physical or moral, is not a sufficient warrant. He cannot rightfully be compelled to do or forbear because it will be better for him to do so, because it will make him happier, because, in the opinion of others, to do so would be wise, or even right...to justify that, the conduct from which it is desired to deter him, must be calculated to produce evil to someone else. The only part of the conduct of anyone, for which he is amenable to society, is that which concerns others. In the part which merely concerns him, his independence is, of right, absolute. Over himself, over his own body and mind, the individual is sovereign (p14).

Clearly, the harm principle allows personal freedom and liberty in the absence of harm to others. Feinberg (1973) helpfully elucidates the concept of 'harm', stating that 'a humanly inflicted harm is conceived as the violation of one of a person's interests, an injury to something in which he has a genuine stake' (p26). Feinberg (1973:25-26) points out that Mill must be understood as including within the harm principle not only violations of individual interests but also of public ones. Husak (1987:231) argues that unless moral reasoning exists to supplement this and explain why the violation of certain interests should be counted as harms deemed worthy of protection, the harm principle would be rendered a useless tautology. When seeking to discern which interests may or ought to be protected by the imposition of criminal liability upon those who perform acts which infringe them, it is useful to consider direct harm to others, harm to the self and harm to the public interest.

First, the criminalization of behaviour which causes direct harm to others is justified by the protection of individual autonomy. Following Mill, the restriction of an individual's liberty through criminalization is justified only to prevent behaviour which causes damage or harm to the interests of others. Mill uses the term 'interest' in this context to mean rights-based interests maintaining that:

[Individuals] should be bound to observe a certain line of conduct toward the rest. This conduct consists...in not injuring the interests of one another; or rather certain interests which, either by express legal provision or by tacit understanding, ought to be considered as rights (p205) [24].

According to the autonomy principle, the intervention by criminal law in the autonomy of individuals is justified on the basis of protecting the rights of others. As noted above, such rights are connected to autonomy and free action insofar as they are considered as entitlements to freely dispose of particular resources in the light of free individual decisions and actions. Following Locke, the moral foundation for criminalization was primarily theorized in terms of universal human rights, understood as private property rights or entitlements of individuals to control and benefit from particular assets without limitations or restriction up until the point where such rights of others are threatened. Locke assumed that individuals have a primary right to ownership of their bodies and bodily powers, meaning that others have no right to contravene these through killing, injuring or enslaving them. This property right of the body was in turn seen to serve as a basis for a legitimate right of ownership of external objects. Threats or actual unauthorized damage to property, life and bodily integrity by others are therefore legitimately outlawed. It is clear

11 See social philosophy of Aquinas at p 15-20; social philosophy of Hobbes at p 31-37; social philosophy of Locke at p 40-44; social philosophy of Hume at 44-46; social philosophy of Rousseau at p48-50; social philosophy of Kant at p 55-60, in Fink H, Social Philosophy, Methuen, London and New York, 1981. 
that the emphasis on offences against the person and property remain central to the theory of criminal law. Within the criminal law, the major crimes remain offences against the person, including assault and battery, wounding, indecent assault, murder, manslaughter, and property offences, including theft, deception, burglary and handling of stolen goods.

In his work Harms to others [25], Feinberg asserts that the legitimacy of prohibition of behaviours through criminalization springs from the prevention of either public or private harm to parties other than the actors. However, not all harmful acts to others can rightly be prohibited, apart from those which cause avoidable and substantial harm. Feinberg remarks that the gravity and seriousness of the harm compared to the social value of the conduct should be taken into account when criminalizing such conduct. He (1984:203) further states that although a certain kind of activity might have a tendency to cause harm to individuals who are affected by it, effective prohibition of that activity would tend to cause harm to those who have interest in doing it. For example, to prevent A from harming B's interest in $\mathrm{Y}$ might result in harming A's interest in X. Feinberg (1984:203) argues that it is for the legislator, using the harm principle, to find a method of comparing the relative importance of conflicting interests to decide whether B's interest in $\mathrm{Y}$ is less or more important than A's interest in $\mathrm{X}$.

Feinberg (1984:204) states that to measure the relative importance of conflicting interests, legislators must consider at least three ways in which interests can differ. First, the vitality of the interest, where some interests are more important than others, such that harming them is likely to lead to greater damage to the interests of individuals and community than harming the lesser important interest. Secondly, interests differ in the degree to which they are reinforced by other private and public interests. A third factor which needs to be considered when balancing opposing interests is their inherent moral quality. Feinberg argues that in certain cases all reasonable persons can be expected to agree that certain interests, simply by their nature, are less worth protecting than others. For example, the sadist's interests in having others suffer pain are a morbid interest, which can be overridden or outweighed to protect others from suffering such pain. Feinberg (1984:206) claims that it is unlikely to be conducive to the public good to encourage development of the character flaws from which such interests spring, and that even if social advantage in individual vices existed, there would be a case against protecting their spawned interests, based upon their inherent unworthiness.

The second type of harm concerns harm to self. As stated earlier, the principle of autonomy allows the criminalization of an individual's behaviour only when harmful to others. This means that if a particular behaviour is not harmful to others, such as the possession of drugs and/or drug dealing and consumption, then it should not be considered criminal. However, as Ashworth (1999:54) comments, the justification for the criminalization of such behaviours and the imposition of criminal liability are usually advanced on the basis of the remoteness of harm and the principle of 'paternalism'. Paternalism involves the interference with another's liberty based on reasons referring to his or her welfare, good, happiness, and the protection of actors from potential harm they may inflict on themselves. In his work Harm to Self, Feinberg rejects 'paternalism' as a relevant and good reason for criminalization, as it rests on a lack of trust which is normally owed to adults [26]. In a similar vein, Roberts (2001-2002) drawing on the work of Feinberg also rejects paternalism as a general basis for criminalization stating that 'paternalism is regarded with suspicion in contemporary western culture, and with good reason, since it competes with values of liberty, personal autonomy, and individual choice that people in liberal societies hold dear' (p228).

However, in this case utilitarian justification supports the limiting of an individual's liberty on the ground of 'paternalism'. From a utilitarian perspective, it can be argued that leaving individuals to engage in harmful activities poses the risk of self-harm, possibly leading to more disadvantages than advantages to the self and the community. In other words, to prevent intervention in another's liberty concerning potentially harmful behaviours such as drug dealing may in fact deprive that person of his or her autonomy and consequently affect the welfare of the community. Von Hirsch (1996:260 - 270) points out that the reasons for the criminalization of remote harms lie in the likelihood and magnitude of the harmful consequences which might ensue. Von Hirsch (1996:266) states that if, for instance, widespread use of a given drug would lead to lowered social productivity which, in turn, would create a criminogenic social environment, and then the prohibition of such a drug would depend on an estimate of the likelihood and magnitude of such effects. He further argues that the normative basis for the imputation of the harmful consequences to the actor lies in an obligation to cooperate: we ought to work together for the sake of our joint interests by preventing certain harmful consequences [27].

Thirdly, public harm is based on the definition of the principle of welfare as outlined above, and is mainly concerned with actions which might be harmful to society, damaging its interests and consequently affecting its well-being. Food safety, health, public safety and security and pollution, are examples of collective social interests which the imposition of criminal liability might be justified in protecting. Feinberg (1984:222-223) argues that the harm principle can be used to justify the prohibition of certain conducts deemed harmful to the public interest. He acknowledges that the notion of public interest is vague and has an elastic nature, although in general there are two connected conceptions by which a public harm can be identified. According to Feinberg (1984:222-223), the first involves a collection of specific interests of the same kind possessed by a large number of private individuals. While these do not necessarily belong to everyone, they could belong to anyone. Public harm in this sense is produced by generally dangerous activities that threaten no specific person but may threaten anyone in a position to be affected. For example, poison dropped into a water supply would cause public harm in this sense; not necessarily harming anybody, but causing a common danger to all. Regarding the second conception, Feinberg (1984:223) states that public interest is common or widely shared specific interests, shared by all or most persons in a community. Almost everyone has an interest in the prevention of crime waves, riot, contamination of the environment, and in maintaining public services whose collapse would constitute a public harm. He (1984:225) claims that the rationale for protecting shared interests is their importance to those who share such public interests, which derive considerable weight from social reinforcement. It may be worth stating that the ranges of activities which can potentially harm the community are generally the result of corporate rather than individual activities. The practices of corporations in areas such as occupational health and safety producing, unsafe products, pollution and rendering workers redundant so as to create unemployment leading to possible criminality are but several examples.

The 'harm principle' offers an explanatory justification for the criminalization of behaviours directly and indirectly harmful to 
individuals and community. However, it is questionable whether this principle offers a proper justification for the criminalization of behaviours which are considered by some to be harmless. These might include so called victimless crimes such as prostitution and consenting homosexual or heterosexual intercourse between adults. Clearly, the requirement of direct harm as grounds for criminalization does not support the criminalization of such behaviours. In addition, the 'harm principle' in conjunction with the autonomy principle relates to adult individuals who are capable of choosing their actions, and therefore the criminalization of their harmless behaviours is groundless. It bears asking whether or not the justification for the criminalization of such behaviours lies elsewhere ${ }^{12}$.

Proponents of the principle of individual autonomy might accept a degree of 'paternalism' through the intervention of criminal law to protect children from engaging in activities harmful to them such as drug and alcohol consumption. However, they reject the intervention of criminal law on the same grounds where the individuals concerned are adults (Findlay et al, 1999:3; Murugason \& McNamara, 1997:5-6). Also, much of the controversy surrounding the harm requirement as grounds for criminalization and imposing criminal liability revolves around the criminalization of incomplete crimes such as attempt where no physical harm has occurred, as well as many regulatory offences such as driving without seat belts. The difficulty is that although these types of behaviours are apparently harmless, they give rise to criminal liability. However, the criminalization of these behaviours could be upheld on the grounds of the prevention of future potential harm, along with a utilitarian ground: criminalization in order to avoid the visiting of hardship on both the individuals involved and the community as a whole.

In sum, this section has considered the 'harm principle' as a moral foundation for criminalization and the imposition of criminal liability. Distinctions between harm to others, harm to self and harm to the community were considered. The discussion has shown that the emphasis on individual autonomy requires intervention by the criminal law to prevent harm to others. In the same vein, the community welfare principle allows such intervention to protect the interests of the community. It is important to note that considering harm beyond direct harm to individuals provides a broader understanding of criminalization. The justifications differ for the types of harm as outlined above. For example, the justification for criminalizing direct harm to individuals hinges upon the protection of their rights as identified by reference to the principle of individual autonomy. Such criminalization also finds support by reference to community welfare ideas in the sense that it may deter others from engaging in harmful behaviours. Moreover, the justification for criminalizing actions which are harmful to the self lies in providing protection to the individual concerned and the community. Drug dealing and consumption, for instance, affect both the individual concerned as well as the community, as various resources need to be allocated to deal with such matters. However, it is worth noting that harm is an evolving concept: what might be considered harmful today may not have been considered so some years ago, and it may not be so in the future. Thus, it is the legislature's task to stay alert to the relative nature of the concept of harm by revising and updating the law accordingly.

\section{The moral notion of harm}

Much of the controversy surrounding the discussion of the moral foundations of criminalization and the imposition of criminal liability relates to the question as to whether certain types of behaviours should be criminalized because of 'individual intuition' of their immorality. In other words, should criminal law be concerned with the prohibition of certain behaviours because they are offensive according to some individuals and might threaten the social cohesion of society? As will be seen below, Lord Devlin contended that society is bound by a common morality which should be preserved and protected. Is there any common morality beyond the prevention of harm to individual rights and autonomy and the welfare of the community, as discussed above, which criminal law should be concerned to preserve? And does such common immorality constitute sufficient grounds for criminalization and the imposition of criminal liability ${ }^{13}$ ?

The discussion of immorality as a ground for criminalization became significant in the realm of sexual behaviour in the 1960s and was subject to a debate between Lord Devlin in his work The Enforcement of Morals in 1965 and HLA Hart in his work Law, Liberty and Morality in 1962. This debate was a response to the report of what is known as the 'Wolfenden Committee' on homosexual behaviour and prostitution, which asserted that there should be a realm of private morality which is not the law's business. Although the report argued for an individualistic perspective following Mill's principle, it accepted some intervention by the criminal law to protect the vulnerable (such as children) against exploitation and corruption. This can be justified on paternalistic grounds. However, as mentioned earlier, liberals reject the imposition of criminal law on the same grounds in order to protect adults. Therefore, how can intervention in the liberty of individuals be justified in this case? It is arguable that Lord Devlin in The Enforcement of Morals 1965 in effect advocated a communitarian perspective and maintained that society is entitled to the use of criminal law to preserve its own existence. Lord Devlin argued that society means a community of ideas, and without that shared ideas on politics, morals, and ethics no society can exist. Society is not something which is kept together physically; it is held by the invisible bonds of common beliefs. A common morality is thus part of the cement holding society together. He also argued that societies disintegrate when no such common morality is observed. As deviation from common morality affects the cohesion of society, it is necessary to criminalise immoral behaviour. Lord Devlin claimed that if society has no right to make judgment on morals, then the law must find a special justification for entering the field of morality. In this context, if homosexuality and prostitution are not in themselves wrongs, it is the task of the lawmaker who wishing to frame a law against certain aspects to justify their criminalisation. However, if society has the right to pass judgment on morality, and does so, then it may use the law to prevent and punish immoral behaviours as it does to safeguard anything else necessary for its existence. The test adopted by Lord Devlin to discover common morality is what he referred to as 'the man in the jury box': assembling of a group of ordinary people in a form of

12 This question will be discussed further when the 'moral notion of harm' is considered.

13 Generally see Clarkson C M V \& Keating H M, Criminal Law: Text and Materials, 3rd ed, Sweet \& Maxwell, London, 1994 at 3-12; McAuley F \& McCutcheon J P, Criminal Liability a Grammar, Round Hall Sweet \&Maxwell, Dublin, 2000 at 65-70; Brown, D \& Farrier D \& Egger S \& McNamara L, Criminal Law: Materials and commentary on the criminal law and process in New South Wales, 3rd ed, The Federation Press, Sydney, 2001 at 99-108. 
a jury and asking them to pass judgment on certain behaviour. If the conduct arouses feelings of indignation or revulsion in these people, then it is a sufficient indication that this behaviour is immoral since it contravenes the common morality, and should thus be a proper object of the criminal law.

HLA Hart in his work Law, Liberty and Morality, rejected Lord Devlin's argument. Hart argues that the claim made by Devlin that society depends on a shared and common morality has not been proven. Furthermore, Hart contends that even if this claim were true, it is not clear that moral sentiment against homosexuality is a necessary part of the common morality. Hart asserts that as the stock of moral beliefs changes from time to time, it is not clear whether homosexuality was simply another case of change rather than behaviour which would lead to the disintegration of morality and consequently society.

Obviously, accepting individual intuition regarding the immorality of behaviours as a sufficient ground for criminalisation is a controversial matter. However, when assessing this ground a number of observations can be made.

First, the problem with Lord Devlin's argument is that it relies on the mere feelings of ordinary people that certain behaviours are immoral. While he acknowledges that moral judgments can be derived from religion, he points out that law can no longer rely on doctrines in which people are entitled to disbelieve. That is, if religion is to be taken as the source of morality, any effort to persuade those who do not hold the same religious belief of the truth of certain moral principles will meet with failure. For example, in NSW, adultery and homosexual intercourse between consenting adult are not crimes, whereas in Jordan they are, as moral judgment on what is right or wrong in Jordan is largely derived from religion. Therefore, in order to avoid the futility of religious disagreements about the description of moral principles, and as the method provided by Lord Devlin to make moral judgments rests on mere feelings of disapproval or disgust of ordinary persons, it is necessary to look for other sources to rely upon for deciding issues of morality. These sources should be grounded in reasons, consistent with other standards used by persons to make a moral judgment. In order to provide a consistent and constructive approach to making moral judgments, guidance can be sought by invoking certain basic ethical/moral theories and concepts such as deontological and rights theories and utilitarianism ${ }^{14}$, as discussed earlier.

Secondly, as Ashworth et al. [7] points out, the method adopted by Lord Devlin to discover immoral behaviour, namely mere feelings of ordinary persons, would confuse moral judgements with prejudice, and may fail to reach agreement on the criminalisation of certain behaviours. That is because neither all immoral behaviours are crimes nor all crimes immoral ${ }^{15}$. For example, although adultery, and homosexual intercourse and extra-marital heterosexual intercourse between consenting adults might be viewed as morally wrong, in NSW they are not crimes, whereas in Jordan they are. Conversely, treason and some regulatory offences such as driving without seat belts are crimes although they are not necessarily immoral. The point is that despite the fact that morality might be an element in many crimes, it fails by itself to explain criminalization [28].

Thirdly, the offensiveness of behaviours is one of the factors usually associated with immorality when the issue of criminalisation of certain behaviours is discussed. The idea of offensiveness involves a publicprivate place distinction. Thus, what individuals may carry out legally in private might be regarded as criminal if conducted in a public place. For example, sexual intercourse between a married couple and homosexual intercourse between consenting adults are permissible if conducted in a private place, but legally prohibited if conducted in public. The criterion of offensiveness forms the basis of a range of criminal prohibitions in the area of public order offences such as indecent exposure, pornographic literature, using indecent language and public drunkenness. Feinberg (1999:118-122) argues that there are many human experiences which are harmless in themselves, yet offensive and so unpleasant that we can rightly demand legal protection from them even at the expense of another's liberties. Feinberg supports his argument by providing a hypothetical example of 'a ride on the bus', inviting the reader to imagine certain behaviours such as nudity and sexual intercourse which might be normal if done in private but offensive if committed in public.

In summary, although immorality by itself does not offer a sufficient explanation for the criminalisation of all wrongdoing, it still operates to allow criminalisation of certain behaviours, and consequently justifying the imposition of criminal liability.

\section{Conclusion}

This paper sought to address and identify the moral foundations for the imposition of criminal liability through exploring the answer to the question 'what is a crime?' The answer is not clear-cut. An exploration of the moral foundations of criminal liability through answering this question has been considered from two possible perspectives. The first is referred to as the 'positivist theory' and the second the 'nonpositivist theory'. It has been demonstrated that the emphasis of 'positivism' in defining crime and providing a justification for the criminalisation of certain behaviours and the imposition of criminal liability is on factors outside the scope of morality. On the other hand, it has been illustrated that 'non-positivist theory' seeks to provide a moral justification for criminalisation and the imposition of criminal liability. It has been shown that these justifications involve consideration of the overlapping and interrelated issues of protecting individual autonomy, individual rights, community, welfare and the underlying issue of harm in its various forms.

It is worth emphasising that all the ethical theories, ideas, concepts and principles, discussed in this chapter have influenced criminal law in one way or another. The emphasis on the protection of individual autonomy and rights is reflected in the criminalisation of behaviours which cause or threaten to cause harm to these rights. For instance, it is a crime to infringe upon an individual's right to life by killing, right to personal safety by causing physical injury, and right to property by stealing or causing damage to it. Furthermore, the emphasis on the prevention of harm to the general welfare and common good of the

14 For further discussion on this concept see Ridley A, 1998 supra at 16-34; Gensler H J, Ethics: A contemporary introduction, Routledge, London, 1998 at139-154; Smart J J C \& Williams B, Utilitarianism: for and against, Cambridge University Press, London, 1973 at 9-62.

15 On this point see for example, Murugason R \& McNamara L, Outline of Criminal Law, Butterworths, Sydney, 1997 at 2; Gillies P, Criminal Law, 3rd ed, The Law Book Company Limited, Sydney, 1993 at 6; Wharton F, Philosophy of Criminal Law, WM. W Gaunt \& Sons, INC, U.S.A, 1989 at 19; Waller L \& Williams C R, 1989 supra at 3-4. 
community has resulted in actions such as causing pollution and producing unsafe products being denounced and criminalised by criminal law. Moreover, the justification for the criminalisation of certain offensive behaviours lies in maintaining the common morality of a society.

These theories which seek to address the question 'what is a crime' largely focus on the outcome or potential outcome of the behaviour. This is apparent from the focus on the consequences affecting an individual as a victim of crime, in terms of an interference with individual autonomy or particular rights. The theories also conceive of the community as being the victim of criminal activities, in terms of an interference with community welfare or social cohesion. However, it is clear that the focus on the consequences or potential consequences of the criminal behaviour fails to provide an adequate theory of why an individual can be convicted of a criminal offence when they may not have physically carried out the actions which in themselves caused the criminal consequence.

It is apparent that the exercise of individual autonomy to influence the individual autonomy of another (a co-offender or an innocent agent) is an important reason for criminalising complicit behaviour.

Noticeably, criminal law is not only concerned with the criminalisation of harmful conduct and its consequences (which has largely been the focus of this paper), but also with explaining why the actor should be held accountable for such conduct and consequences. Accordingly, it is important to shift the focus from the consequences of 'criminal' behaviour to explore the culpability of the offender. Issues relating to notions of individual autonomy lies in the heart of exploring the moral foundations of individual culpability. A theoretical account of this issue will be the subject of another paper.

\section{References}

1. Fuber K (1996) Farewell to 'Legal Positivism': The Separation Thesis Unravelling. In: The Autonomy of Law: Essays on Legal Positivism. George RP (Ed), Oxford University Press, New York.

2. Austin J (1998) The Province of Jurisprudence Determined. John Murray, Albemarle Street, London.

3. Hart HLA (1961) The Concept of Law, Oxford University Press, London.

4. Harris JW (1980) Legal Philosophies. Butterworths, London.

5. Kelsen H, Hartney M (1991) General Theory of Norms. Oxford University Press, United State.

6. Findlay M (2001) Problems for the Criminal Law. Oxford University Press, USA.
7. Ashworth A (1999) Principles of Criminal Law. 3rd Edn, Oxford University Press, USA.

8. Hudson BA (1994) Punishing the poor: a critique of the dominance of legal reasoning in penal policy and practice. Manchester University Press in Association With The Fulbright Commission, London.

9. MacCormick DN (1982) Legal Right and Social Democracy: Essays in Legal and Political Philosophy, Oxford University Press, New York, USA.

10. Feinberg J (1989) Harm to Self. Oxford University Press, New York, USA.

11. Fink H (1990) Social Philosophy. Methuen, London and New York.

12. Hohfeld WN (1983) Some Fundamental Legal Conceptions as Applied in Judicial Reasoning. Yale Law Journal 16:28-59.

13. Hoekema DA (1987) Rights and Wrongs: Coercion, Punishment and the state, Selinsgrove: Susquehanna University Press, London and Toronto.

14. Edmundson WA (2004) An Introduction to Rights. Cambridge University Press, UK.

15. Raz J (1986) The Morality of Freedom. Oxford University Press, New York, USA.

16. Mill JS (1962) Utilitarianism, Collins Sons, Great Britain.

17. Lacey N (1988) State Punishment: Political Principles and Community Values, Routledge, London, UK.

18. Fink H (1990) Social Philosophy, Routledge, London and New York,USA.

19. Feinberg J (1990) Harmless Wrongdoing. Oxford University Press, New York, USA.

20. John Stuart Mill (2008) On liberty and other essays, Oxford University Press, New York, USA.

21. Mill JS (1863) Utilitarianism. Collins \& Sons, Great Britain.

22. Feinberg J (1984) Harms to Others. Oxford University Press, New York, USA.

23. Feinberg J (1986) Harm to Self. Oxford University Press, New York, USA.

24. Von Hirsch A (1996) Extending the Harm Principle: 'Remote' Harm and Fair Imputation. Oxford University Press, New York, USA.

25. Devlin P (1965) The enforcement of morals. Oxford University Press, London.

26. Hart HLA (1963) Law, Liberty and Moralit. Oxford University Press, London.

27. Ridley A (1998) Beginning Bioethics: a Text with Integrated Readings. ST Martin's Press, New York, USA.

28. Feinberg TJ (1985) Offense to Others. Oxford University Press, New York. 